\title{
STEAM GASIFICATION OF SOME MONGOLIAN COALS
}

\author{
Tungalagtamir B. ${ }^{I^{*}}$, Enkhtsetseg E. ${ }^{1}$, Chao Lumen ${ }^{1}$, Narantsetseg M. ${ }^{1}$, Avid B. ${ }^{2}$ and Ulziibat B. ${ }^{3}$ \\ 1 Department of Chemical Engineering, Mongolian University of Science and Technology, Mongolia \\ 2 Mongolian Academy of Sciences, Mongolia \\ 3 SGS LLC, Mongolia \\ *corresponding author: e-mail: botungalagtamir_must@yahoo.com
}

\begin{abstract}
The gasification tests for the Alagtolgoi and Ailbayan coal deposits were conducted in the temperature up to $850^{\circ} \mathrm{C}$ using bench scale reactor in order to evaluate product gas composition. Prior to the gasification experiments, the raw coal was pyrolysed in a stainless steel reactor under $N 2$ atmosphere at a temperature of $500^{\circ} \mathrm{C}$ for $1 \mathrm{~h}$. General behavior of the coal conversion was quite similar for both coals. The gasification tests show that an increase in temperature enhances the formation of hydrogen, carbon dioxide and carbon monoxide. The highest yield of hydrogen and carbon dioxide concentrations of the Ailbayan coal are achieved at temperature of $850^{\circ} \mathrm{C}$, which were $2.859 \mathrm{mmol} \cdot \mathrm{g}^{-1} \cdot \mathrm{min}^{-1}$ and $1.054 \mathrm{mmol} \cdot \mathrm{g}$ ${ }^{1} \cdot \mathrm{min}^{-1}$ respectively. However maximum rate of hydrogen for Alagtolgoi subbituminous coal reached around $800^{\circ} \mathrm{C}$. Overall results show that the maximum gasification rate is reached earlier for subbituminous coal than for bituminous coal, but product gas evolution was higher for the investigated bituminous coal.
\end{abstract}

Keyboards: pyrolysis, gasification, product gas;

\section{INTRODUCTION}

Conversion of coal by any of the processes to produce a mixture of combustible gases is termed coal gasification, even though a large number of chemical reactions other than socalled gasification reactions are involved. In other words, the gasification converts solid coal into gaseous products and the product gas can be easily processed to generate other valuable chemical and petrochemical feedstock. The primary emphases of coal gasification may be on electricity generation via integrated gasification combined cycle (IGCC) types, on syngas production for pipeline applications, on hydrogen production, or on synthesis of liquid fuels and petrochemicals as alternative sources of raw materials [1-4].

Mongolia contains vast coal resources within 15 large-scale coal bearing basins. The proved coal reserves of Mongolia are estimated at 20 billion tonnes, although geological reserves could exceed over 175 billion tonnes. The predominant portion of the identified reserves is lignite in the Eastern Mongolia and coking coal in the South Gobi basin. There are also some reserves of crude oil in Mongolia, however the petroleum products are 100\% imported, with nearly all of these coming from Russia and around $1 \%$ coming from China 
and Kazakhstan [5].

The increased utilization of coal is being considered as a means of developing the economy in Mongolia. Development of processing routes involving gasification could potentially play an important role in the near term economic development. Taking into account Mongolia's dependence on imported oil, coal gasification integrated with syngas cleaning process for removal of sulfur component and carbon dioxide can be a reliable clean and efficient energy system. Also it becomes attractive, if you consider issues, like air pollution problem in Mongolia and possibility to produce cheap gaseous fuel (DME), where gasification enables conversion of coal with very low levels of air pollution compared to most existing coal combustion technologies. However, research is needed in the areas of coal quality and characterization, in order to estimate process performance and emissions levels with a view to their tighter control.

For this reason, the opportunity has been taken to investigate the Alagtolgoi subbituminous and the Ailbayan bituminous coals using a suite of bench scale reactors.

\section{EXPERIMENTAL}

The Alagtolgoi and Ailbayan coal samples were screened to a particle size of $0.15 \sim 0.2$ $\mathrm{mm}$ and air dried before use. The proximate and ultimate analyses of the samples are shown in Table 1.

Table 1. The proximate and ultimate analyses of the coal samples

\begin{tabular}{|c|c|c|c|c|c|c|c|c|c|}
\hline \multirow{2}{*}{ Sample } & \multicolumn{4}{|c|}{ Proximate analysis, \% } & \multicolumn{4}{c|}{ Ultimate analysis, \% daf } \\
\cline { 2 - 10 } & $W^{h}$ & $A^{a}$ & $V^{d}$ & $Q, \mathrm{kcal} / \mathrm{kg}$ & $\mathrm{C}$ & $H$ & $N$ & $S$ & O, by diff. \\
\hline Alagtolgoi & 0.9 & 20.8 & 36.44 & 6072 & 60.7 & 3.64 & 1.5 & 1.1 & 33.1 \\
\hline Ailbayan & 0.2 & 12.6 & 25.09 & 7190 & 75.3 & 4.23 & 1.6 & 0.7 & 18.2 \\
\hline
\end{tabular}

The coal gasification tests using a bench scale reactor WFSM-3060TL were conducted. The schematic diagram of the reactor used in experiments appears in Figure 1. The reactor system was mainly composed of a steam generator and a fixed-bed reactor that was made of a stainless steel reactor $(8 \times 350 \mathrm{~mm})$ which was heated by an electric furnace. A product cooling and refining sections and a cooling section for gas products up to $-30^{\circ} \mathrm{C}$ are connected at the reactor outlet area.

The coal samples were pyrolyzed in a stainless steel reactor at a $500^{\circ} \mathrm{C}$ for $1 \mathrm{~h}$. Air dried coal (10 g) was placed into the reactor which was then closed (not hermetically for the gases to be allowed to escape) and heated at a controlled rate of $10^{\circ} \mathrm{C} / \mathrm{min}$. The obtained pyrolysis char $(0.5 \mathrm{~g})$ was used for gasification tests. Argon (Ar) was used as the gasification carrier gas with the flow rate of about $70 \mathrm{ml} /$ $\mathrm{min}$. The reactor temperature was raised from ambient temperature to $500^{\circ} \mathrm{C}$ at a rate of $15^{\circ} \mathrm{C}$ and subsequently $2^{\circ} \mathrm{C} / \mathrm{min}$ to $850^{\circ} \mathrm{C}$, which was maintained for $5 \mathrm{~h}$. Once the temperature reaches $200{ }^{\circ} \mathrm{C}$, distilled water in the form of steam continuously added to the reactor at $0.12 \mathrm{ml} / \mathrm{min}$. The concentration of the synthetic gases formed from the gasification like hydrogen $\left(\mathrm{H}_{2}\right)$, carbon dioxide $\left(\mathrm{CO}_{2}\right)$, carbon monoxide $(\mathrm{CO})$ and methane $\left(\mathrm{CH}_{4}\right)$ were measured using SP2100A gas chromatograph (TCD). 

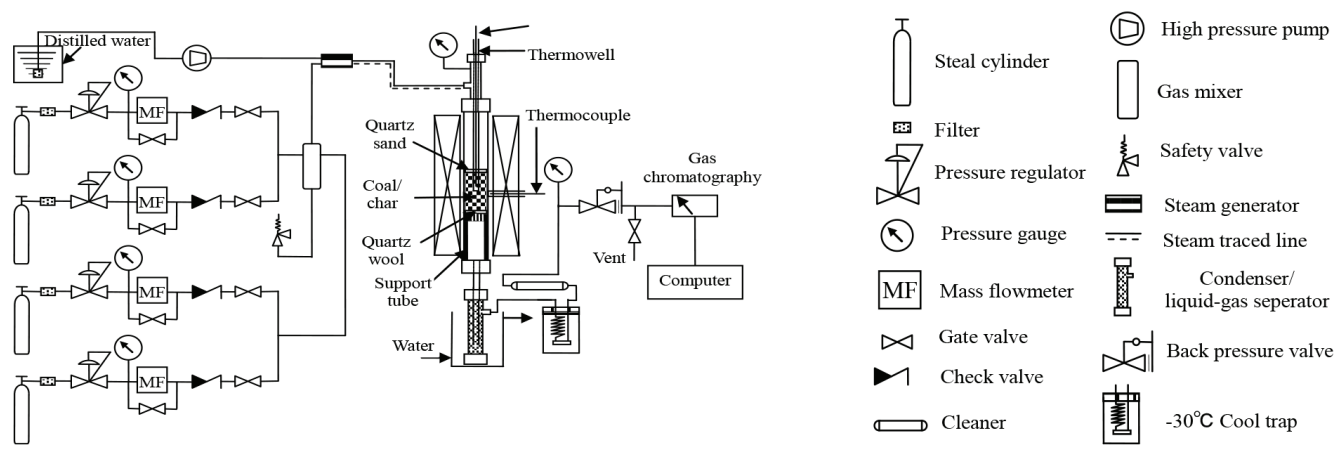

Fig.1. Overall scheme of the gasification test

\section{RESULTS AND DISCUSSION}

Temperature is crucial for the overall gasification process and in present study, reactor temperature was varied from 200 to $850^{\circ} \mathrm{C}$. The results of the coal gasification tests of the Alagtolgoi and Ailbayan deposits were presented in Fig. 2 and conversion behavior of both coals was quite similar. In both figures, the releases of the gases start around $500^{\circ} \mathrm{C}$ and the yield of the evolved gases tend to increase with increasing temperature, however extent of increase of the different product gases were not similar at the various temperatures.
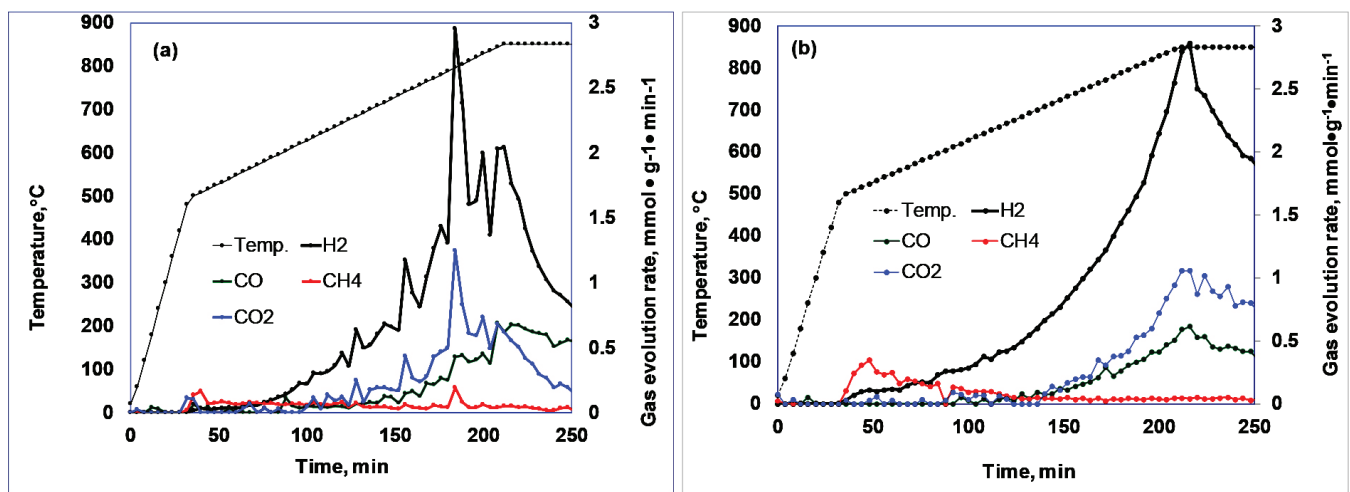

Fig. 2. The yields of gas products from the gasification process of Ailbayan (a) and Alagtolgoi (b) deposits

From Fig. 2, it can be seen that release of methane begins much earlier and finished before other gases evolution. The hydrogen, carbon monoxide and carbon dioxide were started to emit around $650^{\circ} \mathrm{C}$ and the average concentrations of these gases increased continuously with temperature up to $800-850^{\circ} \mathrm{C}$. The maximum evolution of the hydrogen for Alagtolgoi bituminous coal was occurred around $800^{\circ} \mathrm{C}$, while the maximum evolution temperature of the for the Ailbayan bituminous coal occurs at $850^{\circ} \mathrm{C}$. The highest yield of hydrogen and carbon dioxide concentrations of the Ailbayan coal were $2.859 \mathrm{mmol} \cdot \mathrm{g}^{-1} \cdot \mathrm{min}^{-1}$ and $1.054 \mathrm{mmol} \cdot \mathrm{g}^{-1} \cdot \mathrm{min}^{-1}$ respectively. These data were generally higher than Alagtolgoi corresponding data. The concentrations of $\mathrm{H}_{2}$ and $\mathrm{CO}_{2}$ for Alagtolgoi coal were $2.041 \mathrm{mmol} \cdot \mathrm{g}^{-1} \cdot \mathrm{min}^{-1}$ and 0.733 $\mathrm{mmol} \cdot \mathrm{g}^{-1} \cdot \mathrm{min}^{-1}$, respectively. 
From these results, it is apparent that there is a high yield of $\mathrm{H}_{2}$ and very low concentrations of $\mathrm{CH}_{4}$. Also it can be seen that the content of $\mathrm{CO}$ is relatively low with comparison of hydrogen. However, these tests were done in an atmospheric reactor without any catalysis i.e. if we use some catalysis and high pressure, the results will be quite different.

\section{CONCLUSIONS}

- The obtained results show that the maximum product gas evolution occurs at $800^{\circ} \mathrm{C}$ for Alagtolgoi subbituminous and at $850^{\circ} \mathrm{C}$ for Ailbayan bituminous coals.

- The highest yield of hydrogen and

carbon dioxide gases of the Ailbayan coal were $2.859 \mathrm{mmol} \cdot \mathrm{g}^{-1} \cdot \mathrm{min}^{-1}$ and 1.054 $\mathrm{mmol} \cdot \mathrm{g}^{-1} \cdot \mathrm{min}^{-1}$ respectively. These data were generally higher than Alagtolgoi corresponding data.

\section{REFERENCES}

1. S. Lee, J.G. Speight, S.K. Loyalka, Handbook of Alternative Fuel Technologies, 2007, Taylor \& Francis Group, LLC, $525 \mathrm{p}$.

2. K. Vijay Kumar, M. Bharath, Gasification of high-ash Indian coal in bubbling fluidized bed using air and steam - An experimental study, Applied thermal analysis, 116 (2017), 372-381

3. N. Muradov, A. Gujar, J. Baik et al. Production of Fischer-Tropsch hydrocarbons via oxygen-blown gasification of charred pinewood pellets, Fuel Processing Technology, 140 (2015) 236-244

4. E. Aydar, S. Gul, N. Unlu, F. Akgun, H.Livatyali, Effect of the type of gasifying agent on gas composition in a bubbling fluidized bed reactor, Journal of the Energy Institute, (2014) 87 (1) $35-42$

5. B. Avid, Y. Sato, K. Maruyama, Y. Yamada and B. Purevsuren, Effective utilization of Mongolian coal by upgrading in a solvent, Fuel Processing Technology, 85 (8-10) (2004) 933-945 